\title{
Effect of Thermo-mechanical Control Process on Strengthening of a 22Mn-13Cr-5Ni Austenitic Stainless Steel Plate for Cryogenic Use
}

\author{
Souichi IKEDA, Shoji TONE, Shuji TAKASHIMA and Haruo KAJI')
}

Steel Plate and Sheet Development Department, Kakogawa Works, Kobe Steel, Ltd., Kanazawa-cho, Kakogawa, Hyogo-ken, 675-01 Japan. $\quad$ 1) Steel Plate Technology Department, Kobe Steel, Ltd., Tekko Bldg., Marunouchi, Chiyoda-ku, Tokyo, 100 Japan.

(Received on December 13, 1989; accepted in the final form on March 9, 1990)

\begin{abstract}
The effect of thermo-mechanical control process (TMCP) on strengthening of a $22 \mathrm{Mn}-13 \mathrm{Cr}-5 \mathrm{Ni}$ austenitic stainless steel plate for cryogenic use has been investigated by using an intermittent hot compression test. Finish-compression temperature, cooling rate and start-cooling temperature are the factors controlling the recrystallized austenite grain size. 'The austenite grain becomes finer as the finish-compression temperature decreases and as the cooling rate and the startcooling temperature increase in the recrystallization region, all of which are effective for strengthening the steel. On the basis of these results, a steel plate of thickness $70 \mathrm{~mm}$ was produced on a large scale under the optimum TMCP conditions and the mechanical properties of the steel plate were investigated. The TMCP steel attained a higher $0.2 \%$ yield strength than that of the solution heat-treated (ST) steel at $-269^{\circ} \mathrm{C}$, though the fracture toughness was slightly reduced.

KEY WORDS: thermo-mechanical control process; high manganese austenitic stainless steel; recrystallization; grain refinement; strength.
\end{abstract}

\section{Introduction}

The industrial field related to magnetism including nuclear fusion reactors and the Mag-lev transportation system, etc., is in the experimental stage for practical application. High strength non-magnetic austenitic steels are required as the structural materials for such equipment. Solid-solution hardening ${ }^{1,2)}$ using elements such as chromium, molybdenum and nitrogen, precipitation hardening ${ }^{3,4)}$ using vanadium carbide and nitride, and work hardening ${ }^{5)}$ have been generally applied to strengthening of the austenitic steels. Strengthening by the grain refinement has been widely investigated in the field of ferritic steels by applying a thermo-mechanical control process (TMCP). ${ }^{8)}$ However, there are few studies on strengthening by grain refinement in the field of austenitic steels. ${ }^{6,7)}$

In this study, the effect of TMCP on strengthening austenitic steel was investigated using a $22 \mathrm{Mn}-13 \mathrm{Cr}-$ $5 \mathrm{Ni}$ steel for cryogenic use (22Mn steel), and the discussion was restricted to the recrystallized structure which has high ductility and toughness. First, the effect of TMGP on hardness and microstructure in the $22 \mathrm{Mn}$ steel was systematically investigated by an intermittent hot compression test. The effective use of TMCP as a method of strengthening was discussed from a metallurgical viewpoint. Secondly, a 22Mn steel plate of thickness $70 \mathrm{~mm}$ was produced under selected TMCP conditions in a large scale mill. The mechanical properties of the steel plate were investigated and the efficacy of TMCP was discussed.

\section{Experimental Procedures}

The material used was a high-manganese austenitic stainless steel for cryogenic use. The chemical composition is shown in Table 1. The steel ingot melted in a $15 \mathrm{t}$ electric furnace was hot-rolled to a 200mm-thick slab. Cylindrically shaped specimens 8 $\mathrm{mm}$ in diameter and $12 \mathrm{~mm}$ in height were machined from the quarter thickness of the slab in the perpendicular direction. For simulating the actual hotrolling process, the specimens were intermittently hotdeformed with uniaxial compression using a hot deformation simulator.

Fig. 1(a) shows the schematic diagram for the simulated condition, which almost corresponds to that of the actual plate rolling from 200-mm-thick slab to 70-mm-thick plate. The specimens were first reheated to $1200^{\circ} \mathrm{C}$ for $5 \mathrm{~min}$, followed by hot-compression from 12 to $4.2 \mathrm{~mm}$ in 7 passes at the cooling rate of $10^{\circ} \mathrm{C} / \mathrm{s}$. The strain rate and total reduction were $10 \mathrm{~s}^{-1}$ and $65 \%$, respectively. The effects of the finish-compression temperature, cooling rate, startcooling temperature on strengthening were investigated as important process parameters of TMCP. The finish-compression temperature was changed in the range of temperature from 800 to $1000^{\circ} \mathrm{C}$. The average cooling rate from the finish-compression tem-

Table 1. Chemical composition of steel tested.

(wt \% in check analysis)

\begin{tabular}{cccccccc}
\hline $\mathrm{C}$ & $\mathrm{Si}$ & $\mathrm{Mn}$ & $\mathrm{P}$ & $\mathrm{S}$ & $\mathrm{Ni}$ & $\mathrm{Cr}$ & $\mathrm{N}$ \\
\hline 0.04 & 0.34 & 21.82 & 0.013 & 0.004 & 4.94 & 12.84 & 0.23 \\
\hline
\end{tabular}


perature below $150^{\circ} \mathrm{G}$ varied from 0.17 to $30^{\circ} \mathrm{C} / \mathrm{s}$. The cooling rate of $0.17^{\circ} \mathrm{G} / \mathrm{s}$ corresponds to that of as-rolled steel plate with a thickness of $70 \mathrm{~mm}$. The starting temperature of accelerated-cooling varied from 700 to $1000^{\circ} \mathrm{C}$.

The behavior of recrystallization was investigated under the hot-compression and annealing schedule represented in Fig. 1(b). The specimens were first reheated to $1200^{\circ} \mathrm{C}$ for $5 \mathrm{~min}$, followed by hot-compression from 12 to $8.4 \mathrm{~mm}$ in 1 pass. The strain rate and total reduction were $10 \mathrm{~s}^{-1}$ and $30 \%$, respectively. The compression and holding temperature was changed from 900 to $1100^{\circ} \mathrm{C}$. After deformation, the specimens were held isothermally at the same temperature. The holding time varied at intervals between 0.1 and $100 \mathrm{~s}$. The average cooling rate was $30^{\circ} \mathrm{C} / \mathrm{s}$ owing to observing the change of the austenite structure. A solution heat-treated (ST) specimen at $1050^{\circ} \mathrm{G}$ for $5 \mathrm{~min}$ was also prepared to simulate the conventional manufacturing process.

The microstructures of all specimens were observed using an optical microscope after etching with aqua regia at the center of the plane parallel to the longitudinal direction. The austenite grain size was measured by using the circular diameter with an image analyzer. The Vickers hardness (HV $10 \mathrm{kgf}$ ) was measured at the same position as the microstructual observation in accordance with JIS Z2244. Vickers hardness was used as a factor of strength, because the

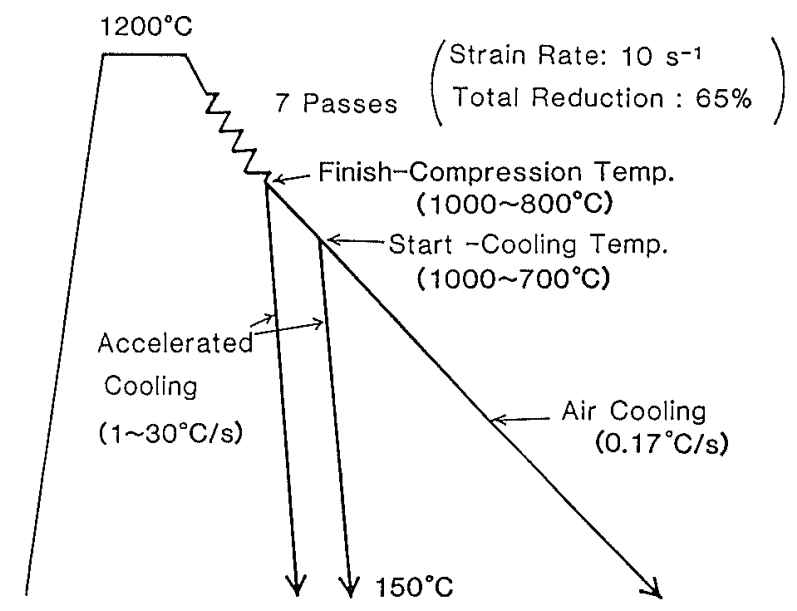

(a) Simulation of hot rolling schedule

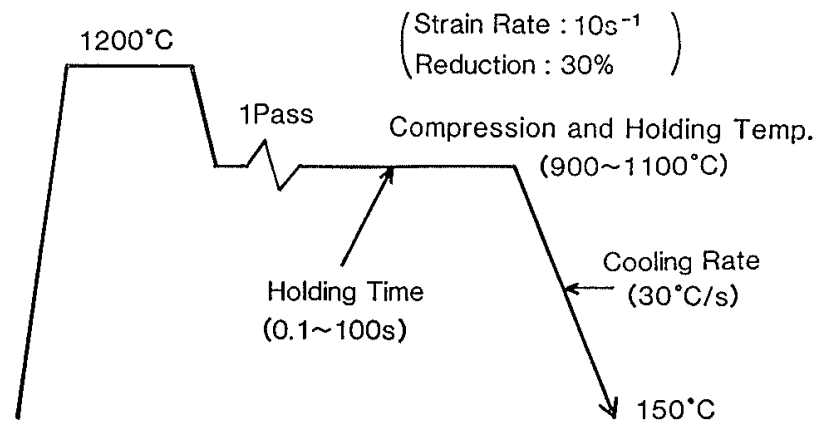

(b) Schedule of hot-compression and isothermal recrystallization

Fig. 1. Schematic diagrams of test condition. specimens were too small to undergo tension test. A good correlation between Vickers hardness and $0.2 \%$ yield or tensile strength was reported by the authors on a $25 \mathrm{Mn}$ austenitic steel. ${ }^{9)}$ The substructures were also observed using a transmission electron microscope (TEM).

Specimens for the tensile test were cylindrical samples of size $7 \mathrm{~mm} \phi \times 50 \mathrm{~mm}$ (at a reduced section) taken perpendicular to the rolling direction from the quarter thickness of the plate. A $10 \mathrm{t}$ cryogenic tensile testing machine ${ }^{10}$ ) was used for the tension test, which was conducted at $-269^{\circ} \mathrm{C}$ in liquid helium. Compact tension specimens $25 \mathrm{~mm}$ thick taken from the quarter thickness of the plate in the $T-L$ orientation were used for the fracture toughness test, which was conducted at $-269^{\circ} \mathrm{C}$ in liquid helium by means of the unloading compliance method which was described in ASTM E813-81 standards. ${ }^{11)}$

\section{Results and Discussion}

\subsection{Effect of Finish-compression Temperature on Strength- ening}

The effect of the finish-compression temperature on hardness and austenite grain size is shown in Fig. 2, and the microstructural change with the finish-compression temperature is shown in Fig. 3. In this case, the steels were hot-compressed at the range of finishcompression temperature from 800 to $1000^{\circ} \mathrm{C}$, and then cooled at $0.17^{\circ} \mathrm{C} / \mathrm{s}$ immediately after deformation.

Austenite grains become finer and hardness in-

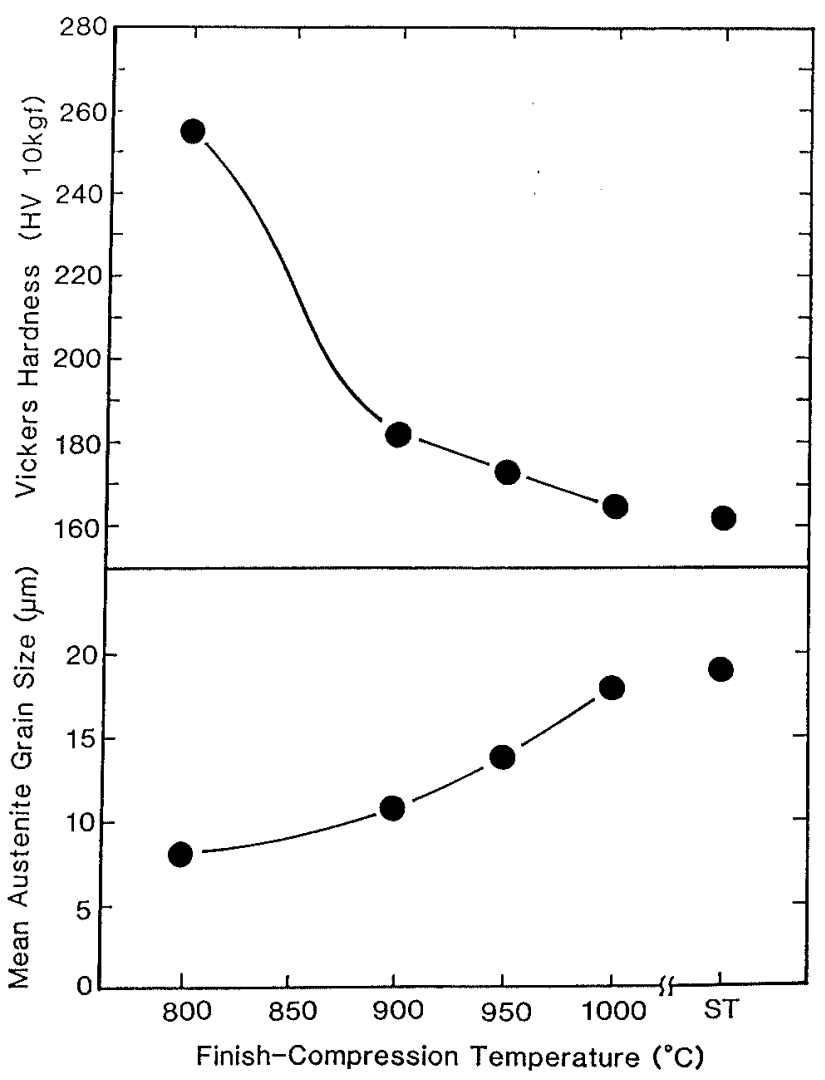

Fig. 2. Effect of finish-compression temperature on hardness and austenite grain size.- - 

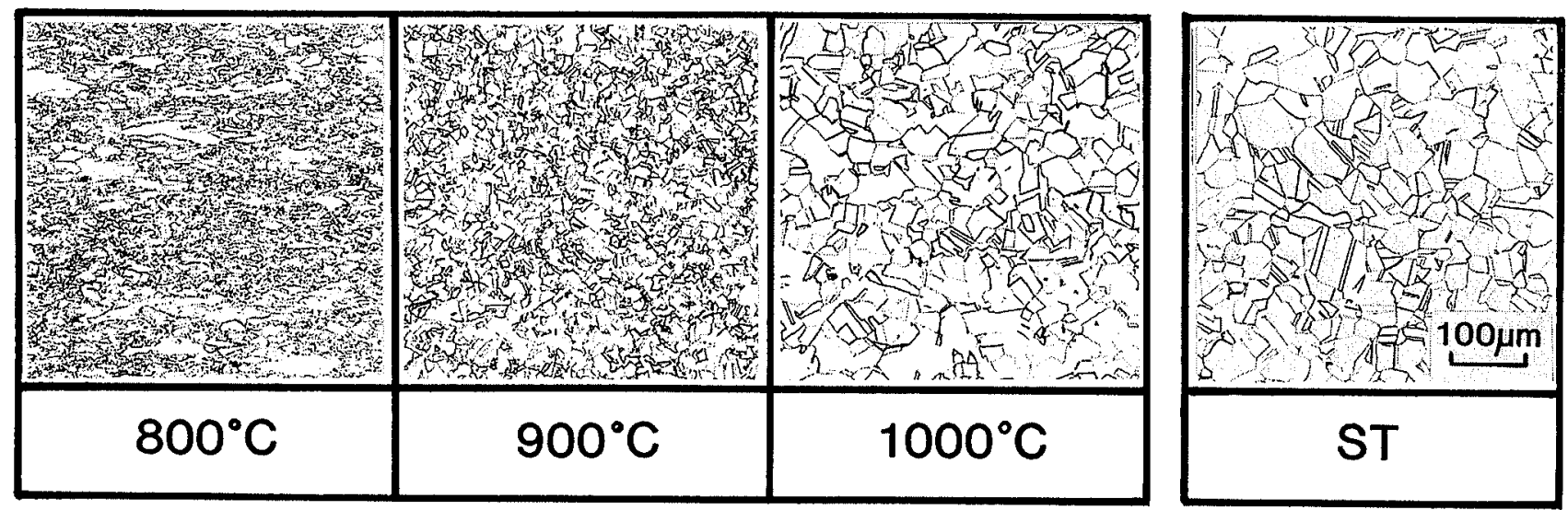

Fig. 3. Microstructural change with finish-compression temperature.

creases as temperature decreases. A rapid increase in hardness takas place at the range of temperature from 900 to $800^{\circ} \mathrm{C}$. Though the hardness at $1000^{\circ} \mathrm{C}$ is almost the same as that of the ST steel at $1050^{\circ} \mathrm{C}$, the hardness below $950^{\circ} \mathrm{G}$ is higher than that of the ST steel. Steels finish-compressed over $900^{\circ} \mathrm{C}$ give rise to a recrystallized structure, while steel finishcompressed at $800^{\circ} \mathrm{C}$ exhibits a non-recrystallized structure as shown in Fig. 3. In the recrystallization region, austenite grains become finer and hardness increases as temperature decreases. Therefore, it is possible to use the effect of grain refinement by hotdeformation on strengthening. On the other hand, though a rapid increase in hardness is observed in the non-recrystallization region, it is difficult to apply it to strengthening because it would be thought toughness decreased. Therefore, the effect of TMCP on strengthening is discussed in the region where the finish-compression temperature is over $900^{\circ} \mathrm{C}$ in the following sections.

\subsection{Effect of Cooling Rate on Strengthening}

Fig. 4 shows the effect of the cooling rate on hardness and austenite grain size after hot-deformation. In this case, the steels were hot-compressed at the finish-compression temperature of $1000^{\circ} \mathrm{C}$, and then cooled from 0.17 to $30^{\circ} \mathrm{C} / \mathrm{s}$ immediately after deformation. The austenite grains become finer and hardness increases as the cooling rate increases. It shuold be noted here that a rapid increase in hardness is observed at the range of cooling rate from 3 to $10^{\circ} \mathrm{C} / \mathrm{s}$, although hardness increases slowly at a cooling range below $3^{\circ} \mathrm{C} / \mathrm{s}$.

Fig. 5 shows the microstructural and substructural changes with cooling range. The steels cooled at 0.17 and $3^{\circ} \mathrm{C} / \mathrm{s}$ exhibit a recrystallized structure with low dislocation density, which is almost the same as that of ST steel. The austenite grains at the cooling rate of $0.17^{\circ} \mathrm{C} / \mathrm{s}$ are coarser than those cooled at $3^{\circ} \mathrm{C} / \mathrm{s}$. This fact shows that the accelerated-cooling acts as a restraint factor of austenite grain growth. On the other hand, the steel cooled at $30^{\circ} \mathrm{C} / \mathrm{s}$ has finer grains than that of the steels cooled at 0.17 and $3^{\circ} \mathrm{C} / \mathrm{s}$, and includes partially-recrystallized structure mixed with the recrystallized structure showing low dislocation density and the non-recrystallized structure showing

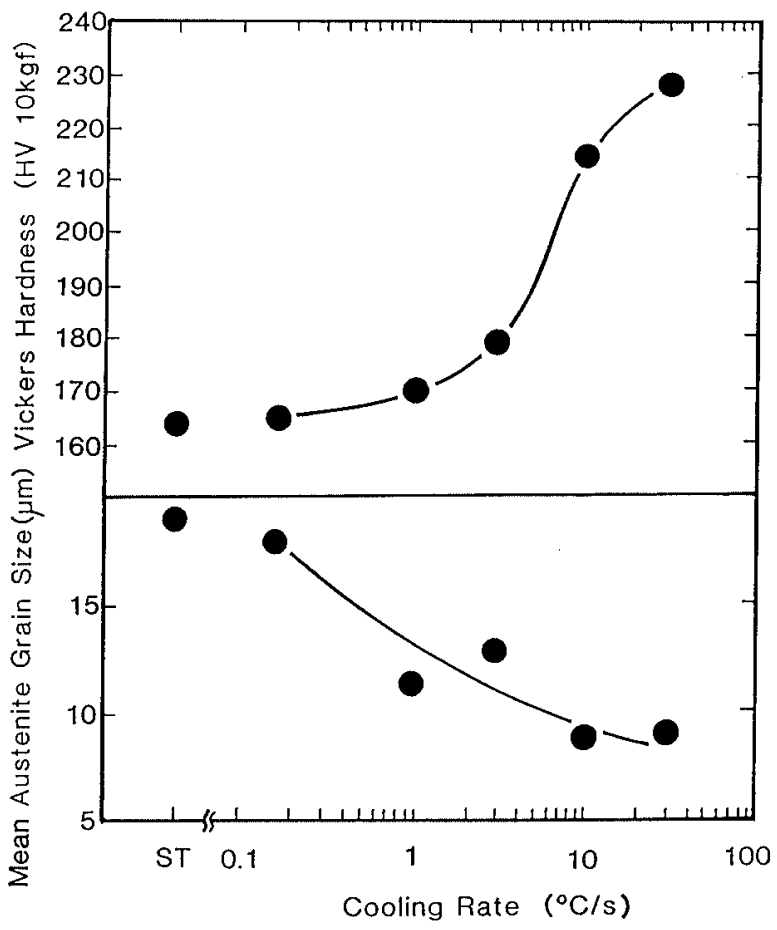

Fig. 4. Effect of cooling rate on hardness and austenite grain size.

high dislocation density. Therefore, the rapid increase in hardness described above can be attributed to such a partially-recrystallized structure. Recrystallization is restrained when the cooling rate is higher than $10^{\circ} \mathrm{C} / \mathrm{s}$.

It is found, from the results above mentioned, that the cooling rate in TMCP divides an austenite structure into a recrystallized, non- and partially-recrystallized structure, and is therefore one of the factors determining the austenite structure. Furthermore, in the recrystallization region, it is found that the cooling rate acts as a factor affecting the austenite grain size. In the case based on such discussion, the lower limit of the finish-rolling temperature where a recrystallized structure can be obtained, should be changed by cooling rate.

Fig. 6 represents the effect of the finish-compression temperature on austenite grain sizes and hardness. In this case, the cooling rate was varied from 0.17 to 

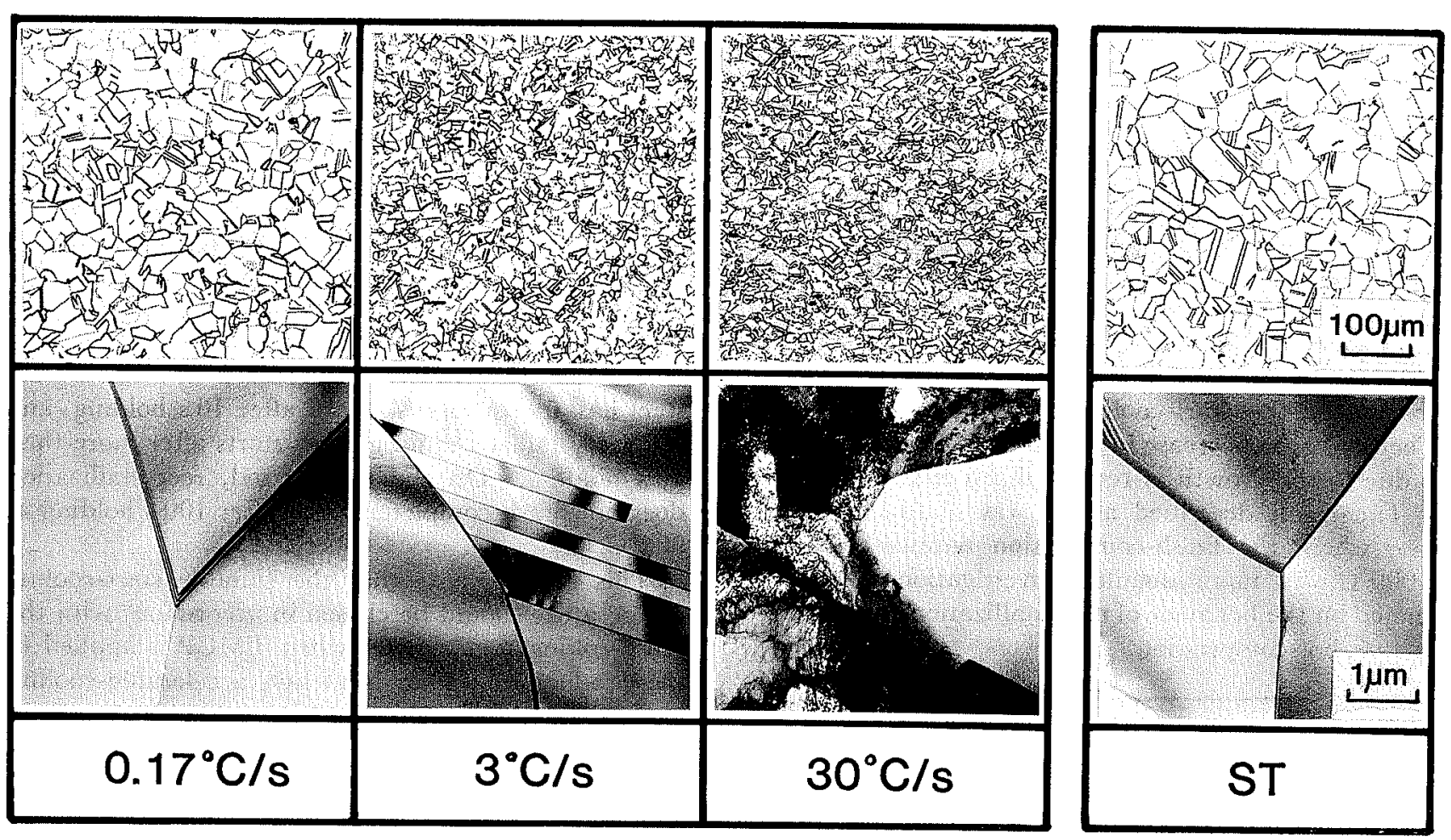

Fig. 5. Microstructural and substructural changes with cooling rate.

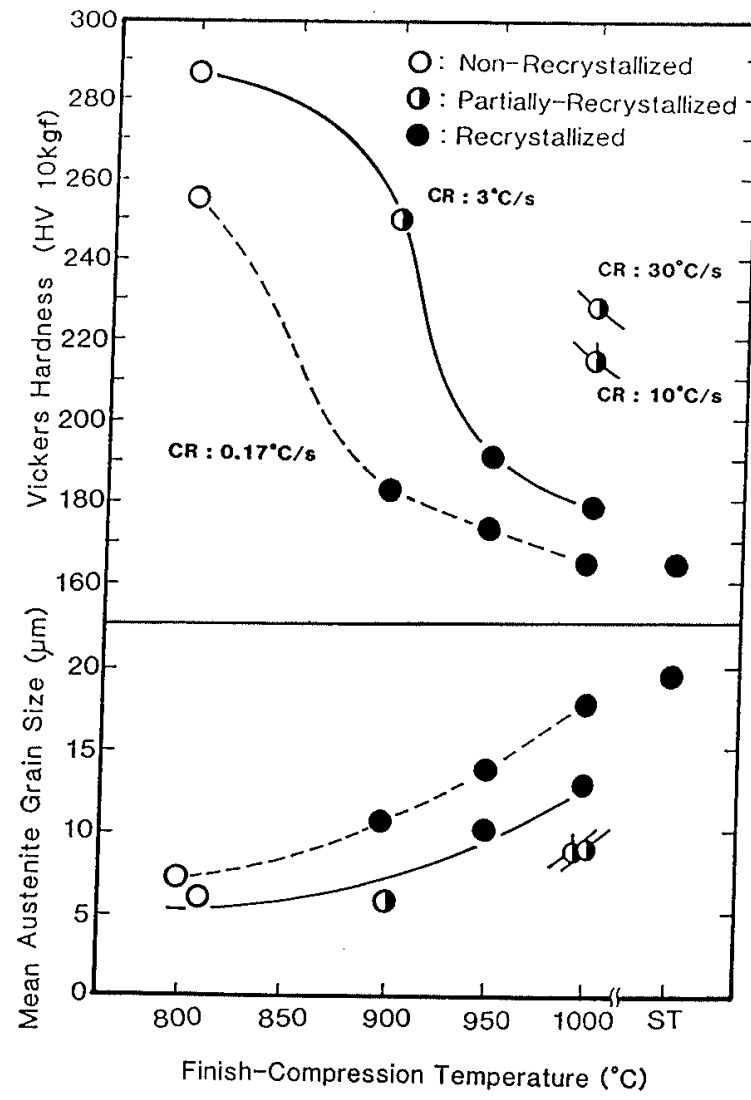

Fig. 6. Effect of finish-compression temperature and cooling rate on hardness and austenite grain size.

$30^{\circ} \mathrm{C} / \mathrm{s}$. The lower limits of the finish-compression temperature where a recrystallized structure can be obtained, are 900 and $950^{\circ} \mathrm{C}$ at the cooling rates of 0.17 and $3^{\circ} \mathrm{C} / \mathrm{s}$, respectively. It is also found that austenite grains can be refined up to about $10 \mu \mathrm{m}$ by

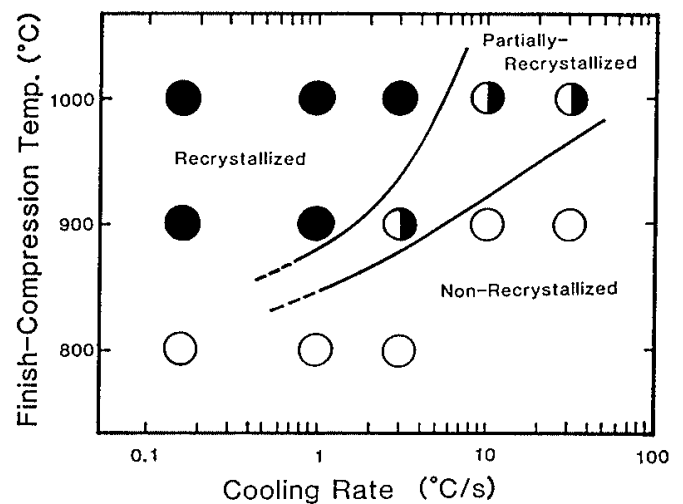

Fig. 7. Microstructural change with finish-compression temperature and cooling rate.

means of selecting the finish-compression temperature and cooling rate. Fig. 7 shows the conditions of the finish-compression temperature and the cooling rate to obtain recrystallized structure. It is needless to say that it would be better to select a condition near the lower limit of the recrystallization region.

\subsection{Effect of Start-cooling Temperature on Strengthening}

Fig. 8 shows the effect of the start-cooling temperature on hardness and austenite grain size. In this case, the steels were hot-compressed at the finishcompression temperature of $1000^{\circ} \mathrm{G}$, and cooled to the several appointed temperatures at $0.17^{\circ} \mathrm{C} / \mathrm{s}$, and then accelerated-cooled below $150^{\circ} \mathrm{C}$ at $3^{\circ} \mathrm{C} / \mathrm{s}$. As the start-cooling temperature decreases, that is to say, as the air cooling time till start-accelerated-cooling increases, austenite grain becomes coarser and hardness decreases. However, hardness scarcely changes and is almost the same as that of steel at the 
start-cooling temperature below $900^{\circ} \mathrm{C}$.

This fact shows that austenite grain size is varied by start-cooling temperature and hardness is consequently controlled. As for the reason why hardness decreases with decreasing start-cooling temperature, it would be thought that fraction recrystallized increased or recrystallized austenite grain coarsened with time.

Fig. 9 shows the microstructural change with startcooling temperature. All of them exhibit recrystallized structure. The recrystallized grains become coarser as the start-cooling temperature decreases. Therefore, the decrease in hardness during air-cooling is due to the growth of recrystallized austenite grain.

The result described above was obtained in the case where the finish-compression temperature was $1000^{\circ} \mathrm{C}$. A more detailed investigation was conducted on the behavior of recrystallization immediately after hot-compression.

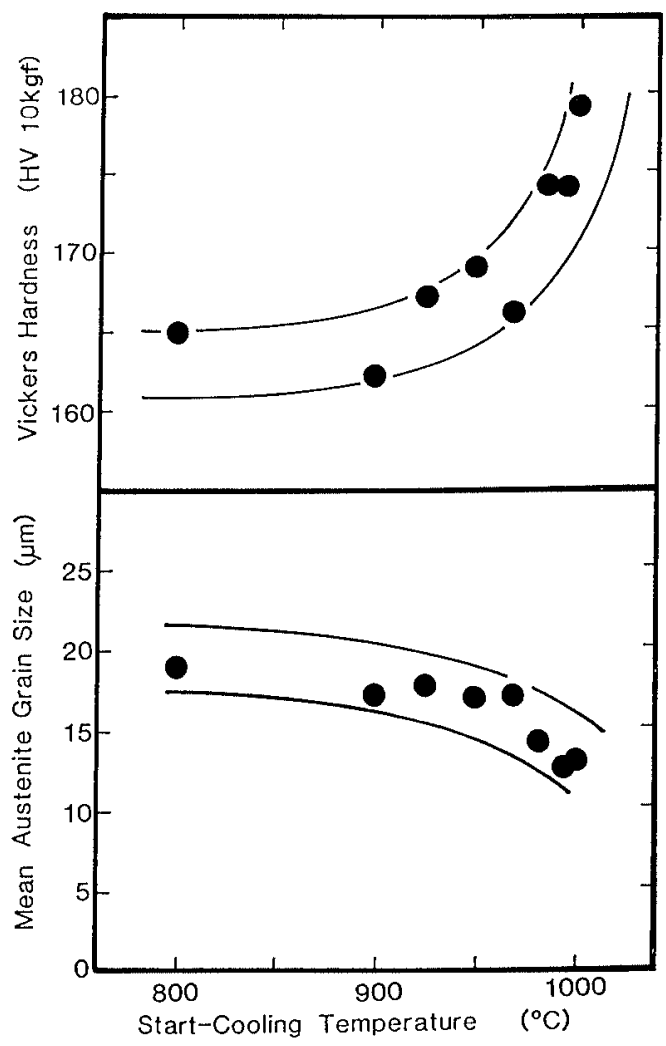

Fig. 8. Effect of start-cooling temperature on hardness and austenite grain size.
Fig. 10 shows the changes in hardness and in fraction recrystallized with holding temperature and time after hot-compression with 1 pass. In this case, compression temperature was varied from 900 to $1100^{\circ} \mathrm{C}$. The steels have almost recrystallized after holding for $10 \mathrm{~s}$ at 1000 and $1100^{\circ} \mathrm{C}$. On the other hand, it needs over $100 \mathrm{~s}$ holding to obtain recrystallized structure at $900^{\circ} \mathrm{C}$.

Fig. 11 shows the microstructural change with holding time after hot-deformation. In the case where hot-compression temperature is $1000^{\circ} \mathrm{C}$, the steel has almost recrystallized after $10 \mathrm{~s}$ holding, and the recrystallized grain growth starts after more than $10 \mathrm{~s}$ holding. On the other hand, recrystallization does not finish completely even after $100 \mathrm{~s}$ holding at $900^{\circ} \mathrm{C}$.

This fact suggests that the suitable start-cooling temperature should be chosen in accordance with the finish-rolling temperature when TMCP is applied to the production. That is to say, accelerated-cooling immediately after hot-rolling is necessary to restrain the recrystallized austenite grain growth in cases of a high finish-rolling temperature such as 1000 and

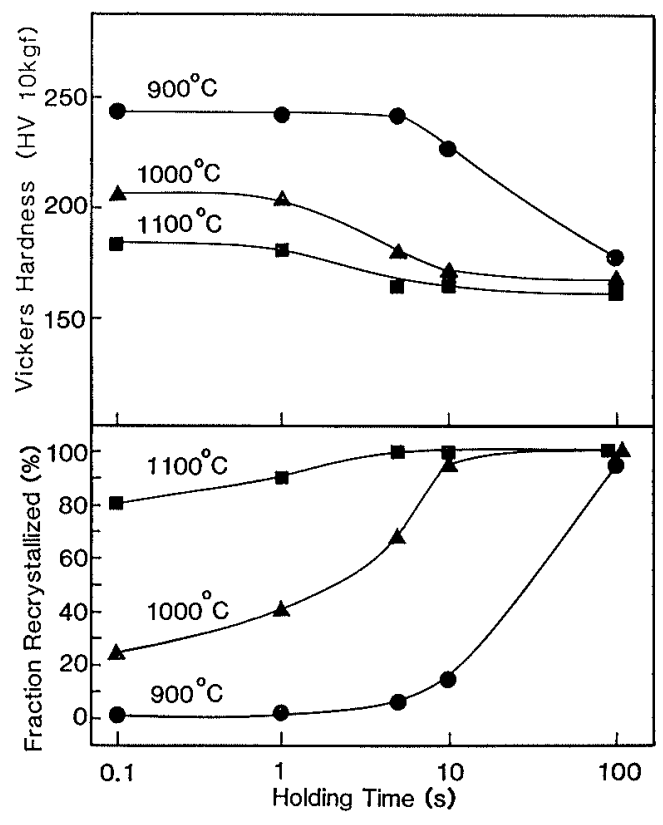

Fig. 10. Change in hardness and fraction recrystallized with holding temperature and time after hotdeformation.

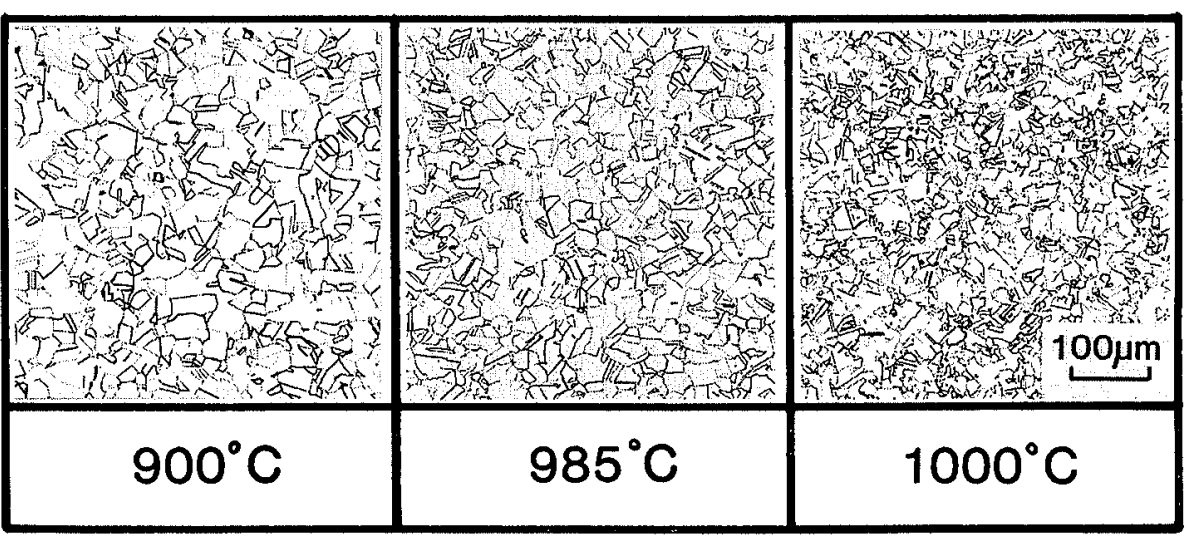

Fig. 9.

Microstructural change with startcooling tomperature. 


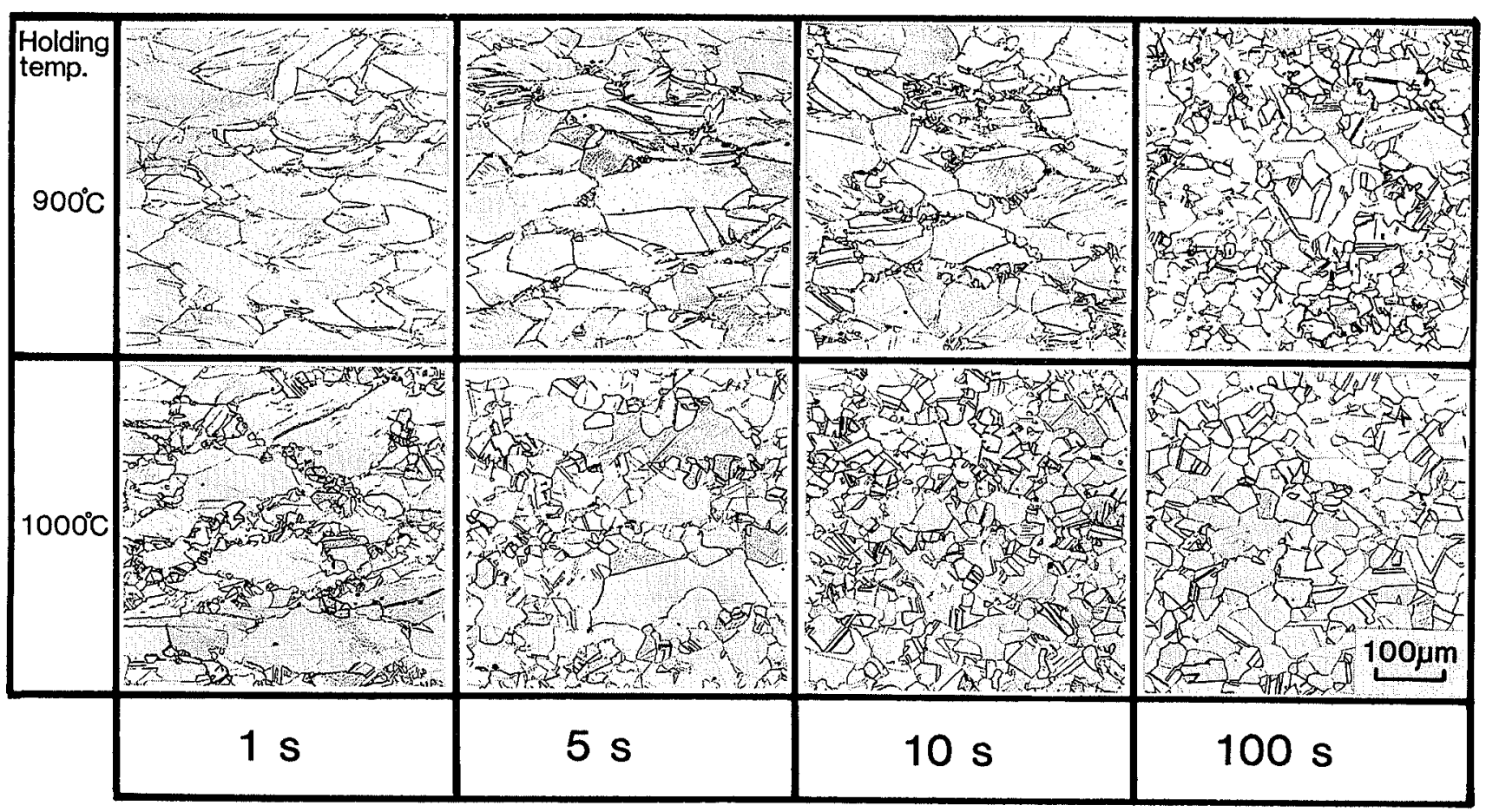

Fig. 11. Microstructural change with holding time after hot-deformation.

$1100^{\circ} \mathrm{C}$. On the other hand, an appropriate interval for air-cooling before accelerated-cooling is necessary to obtain the recrystallized structure in case of a comparatively low finish-rolling temperature of $900^{\circ} \mathrm{C}$.

\subsection{Metallurgical Role of TMCP on Strengthening}

So far, the effect of the finish-rolling temperature, the cooling rate and the start-cooling temperature on hardness and austenite grain size has been investigated. From the results, it was found that these parameters act as the factors determining the austenite microstructure.

Fig. 12 shows the relationship between hardness and austenite grain size. In the recrystallization region, a good correlation exists between hardness and austenite grain size which is not affected by the manufacturing processes, that is, accelerated-cooling, air-cooling and solution heat-treatment. Hardness increases as the austenite grain becomes finer.

Austenite grain can be refined from 20 to $10 \mu \mathrm{m}$ by the application of TMCP to the $22 \mathrm{Mn}$ steel. Consequently, hardness of the $22 \mathrm{Mn}$ steel can also increase from 160 to 190 in $\mathrm{HV}$ in the recrystallization region. In the non- or partially-recrystallization region, the steels have a higher hardness than 210 in HV. However, the use of the non- or partially-recrystallized structure for strengthening is not suitable, because it would be thought these structures caused a deterioration in ductility and toughness of the steel for cryogenic use.

Fig. 13 shows schematic diagrams summarizing the present results on the effect of TMCP. Recrystallized austenite grain becomes finer as the finish-rolling temperature decreases, cooling rate and start-cooling temperature increase, and can be refined up to 10 $\mu \mathrm{m}$ under optimum TMCP conditions. In this case,

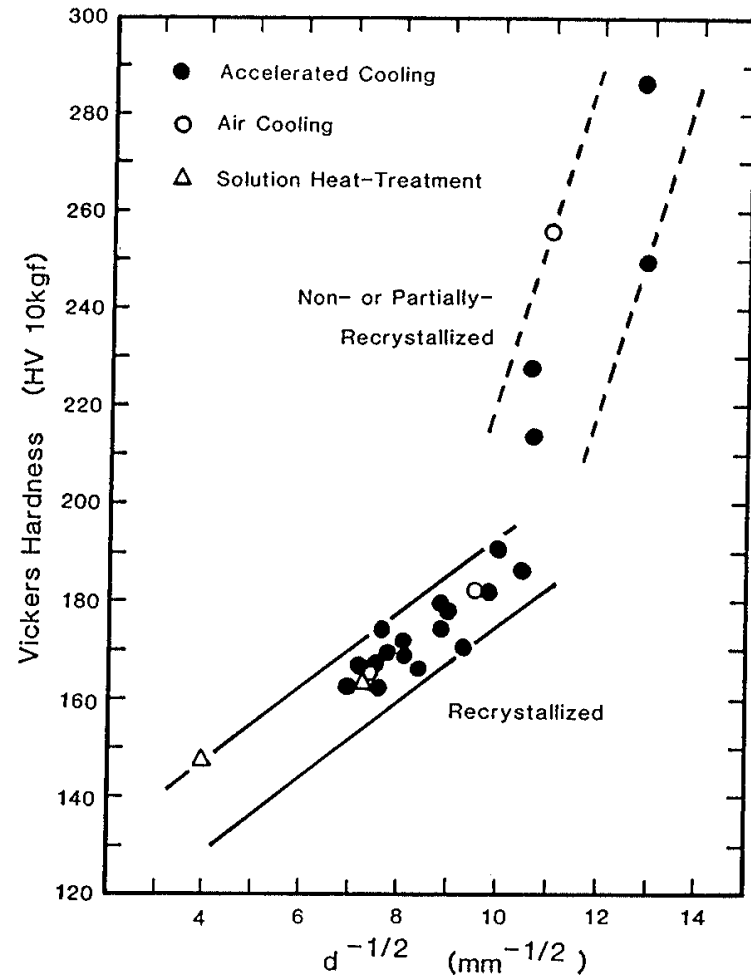

Fig. 12. Relationship between hardness and austenite grain size.

the finish-rolling temperature plays a part in refining the austenite grain, and the cooling rate and the start-cooling temperature play parts in restraining the recrystallized austenite grain growth.

\subsection{Mechanical Properties of TMCP Steel}

The 22Mn steel plate of thickness $70 \mathrm{~mm}$, produced on a large scale under the optimutm conditions dis- 
cussed above, was tested for tensile properties at room temperature and $-269^{\circ} \mathrm{G}$, and fracture toughness at $-269^{\circ} \mathrm{C}$. The steel was first reheated to $1200^{\circ} \mathrm{C}$ and then hot-rolled from 200-mm-thick slab to 70mm-thick plate. In this case, the finish-rolling temperature was $950^{\circ} \mathrm{C}$. After hot-rolling, the steel plate was air-cooled for $50 \mathrm{~s}$ and then accelerated-cooled below $150^{\circ} \mathrm{C}$ at the average cooling rate of $5^{\circ} \mathrm{C} / \mathrm{s}$. As a comparative material, a steel plate solution heattreated at $1050^{\circ} \mathrm{C}$ for $140 \mathrm{~min}$ was also prepared.

Table 2 shows the mechanical properties of the TMCP steel and the ST steel at room temperature and $-269^{\circ} \mathrm{C}$.

The hardness of the TMGP steel, is 189 in $\mathrm{HV}$ at room temperature, is 23 in $\mathrm{HV}$ higher than that of ST one. The result almost accords with that of the simulation test described earlier.

The $0.2 \%$ yield and tensile strengths for the TMCP steel are 358 and $678 \mathrm{MPa}$ at room temperature, and are 1240 and $1659 \mathrm{MPa}$ at $-269^{\circ} \mathrm{C}$, respectively. Both the $0.2 \%$ yield and tensile strengths of the TMGP steel are about $50 \mathrm{MPa}$ higher than those of the ST steel at room temperature, and are about $100 \mathrm{MPa}$ higher than those at $-269^{\circ} \mathrm{C}$.

The fracture toughnesses for the TMCP steel and the ST steel are 194 and $213 \mathrm{MPa} \sqrt{\mathrm{m}}$ at $-269^{\circ} \mathrm{C}$, respectively. The former is slightly reduced in comparison with the latter.

Fig. 14 shows the relationships between $0.2 \%$ yield strength and fracture toughness at $-269^{\circ} \mathrm{C}$ of $22 \mathrm{Mn}$ and AISI Type $304 \mathrm{~N}$ steels. ${ }^{12)}$ The $22 \mathrm{Mn}$ steels have a good balance of $0.2 \%$ yield strength and fracture toughness superior to that of the AISI Type $304 \mathrm{~N}$ steels. The $22 \mathrm{Mn}$ steel produced by TMCP attains a higher $0.2 \%$ yield strength, though the fracture toughness becomes a little lower than that of the ST steel.

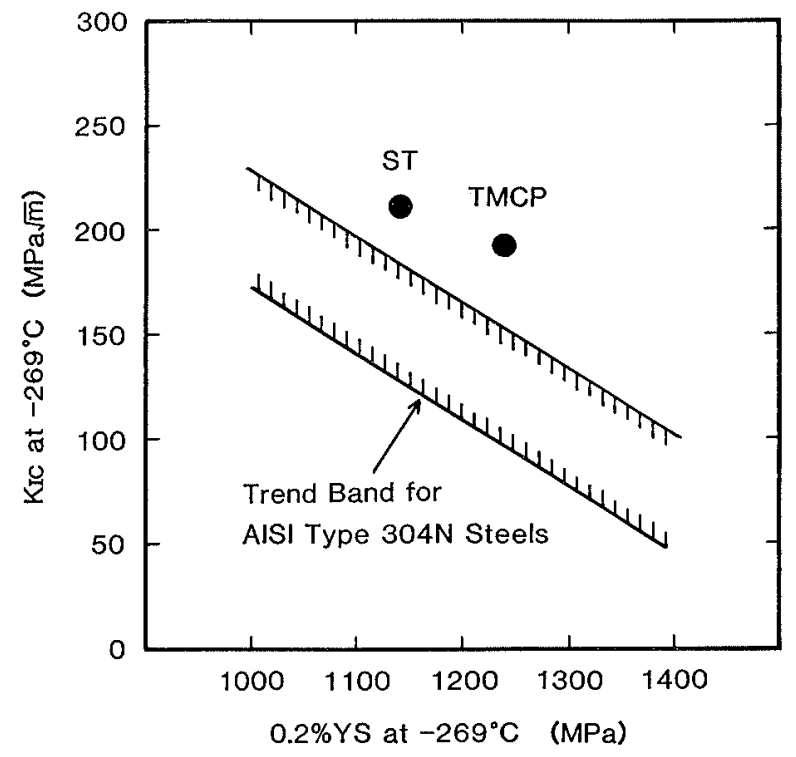

Fig. 14. Relationships between $0.2 \% Y S$ and $K_{\text {IC }}$ of $22 \mathrm{Mn}-13 \mathrm{Cr}-15 \mathrm{Ni}$ and AISI Type $304 \mathrm{~N}$ steels at $-269^{\circ} \mathrm{C}$.
Fig. 13.

Schematic diagrams summarizing results on effect of TMCP.
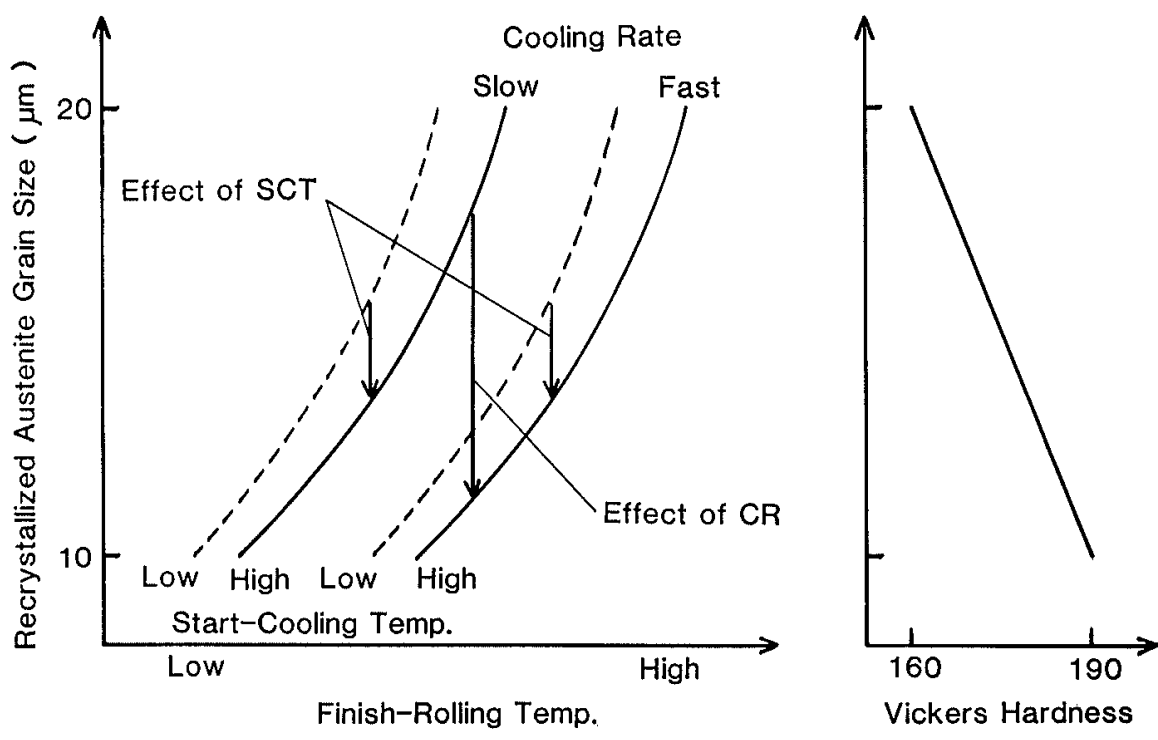

Table 2. Mechanical properties of TMCP and ST type steels.

\begin{tabular}{|c|c|c|c|c|c|c|}
\hline \multirow{2}{*}{$\begin{array}{l}\text { Heat } \\
\text { treatment }\end{array}$} & \multirow{2}{*}{$\begin{array}{l}\text { Test temp. } \\
\quad\left({ }^{\circ} \mathrm{C}\right)\end{array}$} & \multicolumn{3}{|c|}{ Tensile properties } & \multirow{2}{*}{$\begin{array}{c}\text { Fracture } \\
\text { toughness } \\
K_{\mathrm{IC}} \\
(\mathrm{MPa} \sqrt{\mathrm{m}})\end{array}$} & \multirow{2}{*}{$\begin{array}{c}\text { Hardness } \\
\text { HV } \\
(10 \mathrm{kgf})\end{array}$} \\
\hline & & $\begin{array}{c}0.2 \% Y S \\
(\mathrm{MPa})\end{array}$ & $\begin{array}{c}T S \\
(\mathrm{MPa})\end{array}$ & $\begin{array}{l}E L \\
(\%)\end{array}$ & & \\
\hline \multirow{2}{*}{ TMCP } & 20 & 358 & 678 & 63 & - & 189 \\
\hline & -269 & 1240 & 1659 & 37 & 194 & - \\
\hline \multirow{2}{*}{$\mathrm{ST}$} & 20 & 298 & 627 & 70 & - & 166 \\
\hline & -269 & 1145 & 1558 & 39 & $=-213$ & 一 \\
\hline
\end{tabular}




\section{Conclusions}

The effect of TMCP on strengthening in the $22 \mathrm{Mn}-13 \mathrm{Cr}-5 \mathrm{Ni}$ austenitic stainless steel plate for cryogenic use has been systematically investigated by a hot compression test. On the basis of the present results, the steel plate of thickness $70 \mathrm{~mm}$ was produced on a large scale under optimum TMCP conditions, the plates were investigated for the mechanical properties.

The results are summarized as follows:

(1) The finish-rolling temperature, cooling rate and start-cooling temperature are the factors controlling the recrystallized austenite grain size. Austenite grain becomes finer as the finish-rolling temperature decreases, the cooling rate and the start-cooling temperature increase in the recrystallization region. In this case, to lower the finish-rolling temperature plays a part in refining the recrystallized austenite grain, and increase in the cooling rate and start-cooling temperature play parts in restraining the recrystallized austenite grain growth. Austenite grain of the 22Mn steel can be refined up to $10 \mu \mathrm{m}$ by the TMCP and consequently, hardness can be increased about 30 in HV.

(2) The increase in the $0.2 \%$ yield and tensile strengths by applying TMCP is about $50 \mathrm{MPa}$ at room temperature and about $100 \mathrm{MPa}$ at $-269^{\circ} \mathrm{G}$, though the fracture toughness at $-269^{\circ} \mathrm{C}$ is slightly reduced.

\section{REFERENCES}

1) T. Kato, M. Fujikura, S. Yahagi and K. Ishida: Tetsu-toHagané, 67 (1981), 587.

2) S. Yamamoto, N. Yamagami and C. Ouchi: Advan. Cryo. Eng., 32 (1986), 57.

3) M. Endoh and J. Namekata: J.Jpn. Inst. Met., 30 (1966), 734.

4) J. Namekata: Tetsu-io-Hagané, 59 (1973), 272.

5) T. Nakano, T. Goto and M. Maeda: Tetsu-to-Hagané, 50 (1964), 37.

6) T. Sakai, Y. Saito and K. Kato: Trans. Iron Steel Inst. Jpn., 27 (1987), 520

7) K. Matsumoto, S. Tsuyama, Y. Kobayashi and M. Honda: Telsu-to-Hagané, 75 (1989), 329.

8) M. Katsumata, M. Machida, S. Kawata and N. Akiyama: Kobe Steel Eng. Rep., 33, (1983), No. 4, 24.

9) S. Tone and H. Kaji: Int. Conf. on Physical Metallurgy of Thermomechanical Processing of Steels and Other Metals, " THERMEC-88", II, ISIJ, Tokyo, (1988), 872.

10) Y. Takahashi, K. Yoshida, M. Shimada, E. Tada, R. Miura and S. Shimamoto: Advan. Cryo. Eng., 28 (1982), 73.

11) M. Shimada, R. Ogawa, T. Moriyama and T. Horiuchi: Cryo. Eng., 21 (1986), 269.

12) D. T. Reed and R. P. Reed: Materials Studies for Magnetic Fusion Energy Applications at Low Temperatures-II, NBSIR 79-1609, Nat. Bur. of Stand., Colo., (1979), 81. 